\title{
Israeli Teachers' Definitions of Morally Courageous Behavior in Education
}

\author{
Lea Baratz ${ }^{1}$, Roni Reingold ${ }^{1} \&$ Hannah Abuhatzira ${ }^{1}$ \\ ${ }^{1}$ Department of Literature, Achva-College of Education, Israel \\ Correspondence: Roni Reingold, Department of Education, Achva-College of Education, Israel. Tel: \\ 972-522-290-045. E-mail: reingold@netvision.net.il
}

Received: October 20, 2012

doi:10.5539/jel.v2n1p92

\author{
Accepted: October 29, $2012 \quad$ Online Published: January 16, 2013 \\ URL: http://dx.doi.org/10.5539/jel.v2n1p92
}

\begin{abstract}
This paper examines the content fields of the concept of "teachers' moral courage" in order to conceptualize its boundaries. The study's purpose was to assess the dimensions of morally courageous activity within school life by qualitatively analyzing of 17 Israeli Secular Public School Teachers and 14 Israeli Religious Public School teachers' interviewee defined self-narrative.

The findings reveal that the interviewees' answers express a profound understanding about the concept of moral courage, and a content domains definition of morally courageous educational behavior in three realms: the institution, the curriculum and the personal. Moreover, it reveals that the interviewee's claim that the Israeli educational system is characterized by instructional price tags for teachers' morally courageous behavior.
\end{abstract}

Keywords: moral courage, Israeli teachers, moral education, defined self-narrative, school life, ethical code

\section{Introduction}

This paper examines the content fields of the concept of "teachers' moral courage" in order to conceptualize its boundaries. Thus, this paper attempts to identify elements that define behaviors informed by moral courage.

The issue of moral courage of teachers in the Israeli education system is of special significance due to the fact that the Israeli Ministry of Education has complete and centralized control in determining educational policy and activities for all schools in the country (Baratz \& Reingold, 2010). Therefore the Ministry of Education has, subsequently, encouraged conformist behavior of teachers in alignment with these policies throughout the years of the existence of the State of Israel.

In addition, the issue of moral courage is of great importance beyond the context of education in Israel. Since school life is known to present teachers with ongoing moral and ethical dilemmas, teachers are continuously required to make moral decisions concerning which of two "right" choices they deem more desirable (Shermer, 1999) or to choose the least of two "evils" (Sabar, Dushnik \& Bialik, 2007).

In a teaching context, moral courage means the willingness to protect our values publicly. Teachers must have the desire and the ability to discuss ethical issues in order to awaken their students' awareness (Klaassen, 2007, 2012). Teachers cannot be content with merely teaching compulsory knowledge or even with promoting thinking skills (Klaassen \& Maslovaty, 2010). Moral courage among teachers is characterized by a mental challenge. Individuals who take this stance risk damaging their reputation, emotional world, integrity, or self-image ((Klaassen, 2007) An activity of moral courage is connected to the most central values of the person who takes this stance (Kidder, 2005; Klaassen \& Maslovaty, 2010). Some teachers maintain that the task of moral education is a central element in their role as educators and view themselves as agents of critical education and as persons who show great moral courage (Kidder, 2005). Thus, the very understanding of the teachers that moral education is a central aspect of their work is in itself an expression of moral courage (Klaassen \& Maslovaty, 2010).

There is a long philosophical tradition throughout the years that discusses the concept of courage and, in many cases, connects the concept of courage to moral behavior, such as found in the writing of the Fathers of the Christian Church, like Thomas Aquinas; Tillich (1952), Miller (2000) and Klassen (2010) are only a few of the modern philosophers who are engaged in such philosophic discussions. The limited overview of this article requires that we forgot the historical-philosophical discussion in favor of a few definitions of the concept to 
provide a sufficient background for the understanding of the empirical findings.

\section{Theoretical Background}

\subsection{Moral Courage: The Term and Its Nature}

Miller (2000) defines moral courage as "a willingness to take a stand in defense of principles or convictions even when others do not. People who exhibit moral courage are often subject to a number of risks associated with taking a stand, including inconvenience, unpopularity, ostracism, disapproval, derision, and even harm to themselves or their relatives" (p. 36). Moral courage is the ability of individuals to overcome fear and stand up for their main values and ethical commitments (Lachman, 2007), or as Kidder formulates it, "Moral courage is the courage to be moral" (Kidder, 2005, p. 10). He adds that moral courage can be identified by five basic qualities: integrity, honor, responsibility, decency, and compassion. Thus, moral courage is the bridge between talking about values and actually implementing them. According to Kidder (2005), moral courage is presented in the following diagram as the area in which three elements intersect: danger, principles, and endurance.

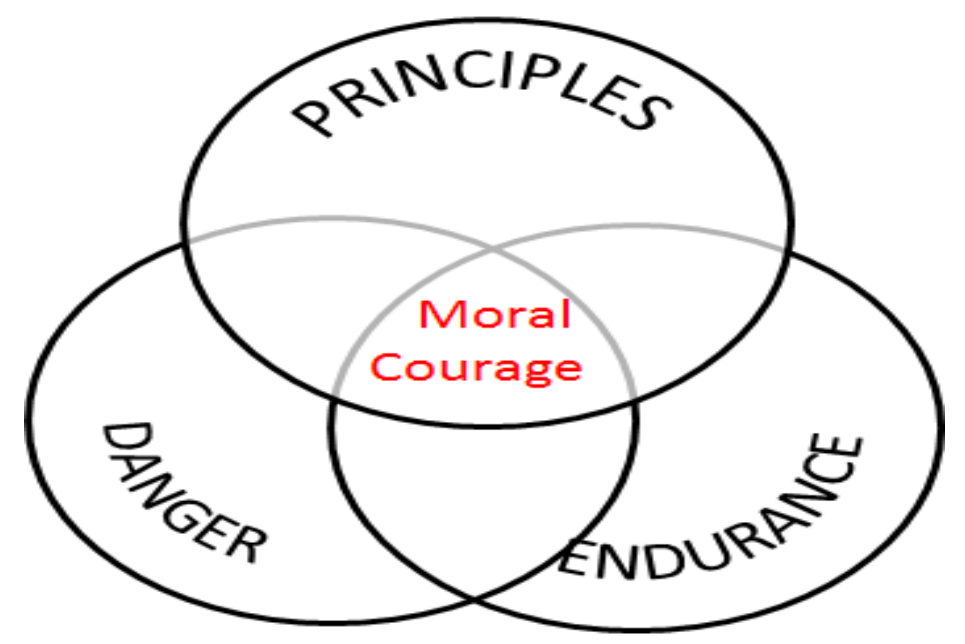

Figure 1. The three elements of moral courage

McCain (2004) suggests a useful differentiation between fears which deal with physical courage and fears which deal with moral courage. While physical courage confronts us with the fear of failure, moral courage quite often confronts us with the fear of success. It is reasonable to assume that individuals will be able to cope with fear of physical injury or death if they can foresee that such an outcome may be the result of the successful performance of a courageous moral act. For example, such foresight helped Martin Luther King to act in order to succeed though he knew that his life was at risk. Nevertheless, McCain's differentiation does not provide a full picture of the connection between the two kinds of courage. Could Martin Luther King have acted on his principles if he had been physically afraid? In his book, The Mystery of Courage, Miller (2000) maintains that people who have moral courage do not have to be physically courageous, but they cannot be physically afraid, since this would prevent them from fulfilling their moral goal. Thus, Martin Luther King did not have to be physically courageous, but neither could he have been physically afraid, lest he would have shied away from his moral goals due to threats or physical actions aimed at endangering him.

Is there also an opposite relationship? Do acts of physical courage oblige the person not to be morally afraid? Rorty (1988), discussing the psychology of morality, puts the issue sharply into focus and explains the need to re-conceptualize courage. She addresses courage as part of her attempt to understand various human virtues and differentiates between the traditional definition of courage and a new definition of courage. According to her, the traditional conceptualization of courage raises various problems concerning its very definition of being a virtue. She believes that there is a need to re-define the question, "What is courage?" Her starting point is the traditional definition of courage as a set of dispositions for overcoming fear of obstacles and performing difficult and dangerous actions. According to her, this definition does not present courage as a virtue, even if it is an important quality from the point of view of survival. She maintains that in order to retain the view of courage as a virtue, 
the cognitive setting should be redefined and placed within a new setting that embeds previously defined qualities such that courageous thoughts or actions would not contradict or threaten other human virtues.

When individuals have a presumption about the concept of courage in its traditional meaning, they will act in order to overcome obstacles. Even when the obstacle or threat is internal (such as a flaw in a person's character or a temptation to adopt a certain mode of thinking), the courageous stand is a combatant one that tends to be confrontational. The objects that are confronted are addressed as external objects that should be overcome. Although courage may be exercised for the advancement of something, it is defined as resistance. When individuals struggle against something that they identify as a part of themselves, the identification is with forces that are under their control, and other parts of the self are detached from them. For this reason, the militaristic conception of a conflict is maintained. A part of the problematic nature of the traditional definition of courage stems from the fact that cultures reward traditional virtues, such as courage. Therefore, these qualities find expression not only in situations in which they are required, but also in situations which are created in order to allow expression of these qualities. A certain virtue, which is central to the personality, turns into a dominant element in the way we interpret situations. As a result, it causes us to regard situations in a way that evokes certain responses and actions. The cognitive presumption influences conception, which in turn, influences action. The presumptions of courage (because of confidence, which is a part of courage) tend to minimize other assumptions, mostly those that that would enable us to avoid conflict, such as empathy or humor.

Graff $(1992,1994)$ writes about the need "to teach the conflict." His program resonated widely in the U.S. in the 1990s, and yielded an extensive academic discussion. Graff's opinion is that a conflict regarding any controversial issue cannot be resolved unless one side, whether conservative, left-wing, or right-wing, forces the other side to succumb, thereby making it comply with the rules of the winning dominant side, since conflicts are immanent and cannot disappear miraculously. "The differences between the various sections in politics and academy are simply too strong for one side to win. We should learn them and teach them" (Graff, 1994, p. 9).

In addition, conflicts should be placed at the heart of the curriculum that is built upon values of a strong and open democracy, knowing that winning is not the issue. It is very important to involve students in the discussion, to present them with contrasting opinions and to cause them to take a stand. This involvement serves to expose students to the issues that adults' debate, enabling them to understand why these issues are so important and to locate their own opinions on the continuum of those presented. "A true democratic education is based on an exchange of ideas and understanding that denial of the other becomes an anti-democratic act (Graph, 1994, p. 10)". Graph claims that, paradoxically, what divides us now can unite us and can serve nonacademic and pre-academic education as an organizing and uniting factor. Furthermore, he notes that although some teachers are involved in debates concerning what should be taught and how it should be taught, they still refrain from including students in these disputations, thereby preventing an essential democratic dialogue to take place.

\subsection{Moral Courage and Professional Ethics}

For functional morality to integrate easily with personal conscience there should be total agreement as to the demands of professional ethics. It is also necessary that the stance held by the individual be congruous with the consensus of the professional community (Zohar, 2000). This is consistent with the definition of professional ethics, which calls for a coherent view of the practical ideal of behavior within a defined professional framework of unique human activity (Kasher, 2003). This framework is based on a systematic body of knowledge, on theory and empirical facts, and is acquired by intentional learning, rather than incidental (Schefler, 2003). Professional ethics deals with ideal professional excellence as it is demonstrated through behavior, action and professional work. Thus, various professions have different formulations of professional ethics, from which rules and premises that characterize, and sometimes even identify the profession and its practitioners, are derived. These rules direct professionals to be the best in their professional field as expressed in proper professional behavior.

In practice, teachers often identify several courses of action that are judged to be appropriate and, yet, must choose only one and pay an ethical price. The conflict is mainly internal, within the teachers themselves, and the considerations are perceived as ethical. While the conflict about doing the right thing is internal, there is external pressure exerted on teachers, making it difficult for them to adhere to ethical clarity. The conflict is between utilitarian considerations: struggling with pressure and the ethical considerations that the teachers want to follow. Such complicated and uncertain situations pose problems that conceal within them moral conflicts (Reshef, 2002).

Clear demands of professional ethics that now define actions as civic behavior of individuals belonging to an organization (Optalka, 2007), would change these actions into part of the job description. This means that tasks and actions would no longer be performed by workers voluntarily for the benefit of the organization and society, 
but rather would be carried out as requirements of their job description. When dealing with teachers' job descriptions, including the areas addressed by professional ethics, the scope of the discussion is widened. According to Sabar et al. (2007), ethical questions involve the following issues: evaluating students, enforcing disciplinary rules, balancing the individual good against the common good of the class, students' right for privacy; encounters between different worldviews and, relationships between teaching staff and parents and between teachers and their colleagues.

In the Israeli education system, there is no professional ethical code as existing in the professions of medicine, psychology and social work. Instead, the foundation of the profession rests upon the management circular of the Ministry of Education. This circular is divided into "regulations" and "announcements and information" by which the role of the teacher is defined. In the management circular, it is stated that (page 1) the education system seeks to educate its pupils to become actively involved and law-abiding citizens with moral standards and critical thinking skills to loyally serve their country. Educational personnel are responsible for the educational and scholastic training of pupils and their articulations and actions may have a significant influence on the attitudes and opinions of pupils.

However, together with the activities of the teachers in the classroom as educators and civil servants, they are also entitled to rights as citizens in a country that endeavors to allow them to maintain and promote their political and party affiliations. In such cases, there is a need to make a clear distinction between the teacher in the role of educator and the teacher as a private citizen who has the right to vote and to be elected, to exercise freedom of speech, to demonstrate and etc. It is important to mention that these regulations are not intended to limit the rights of the teachers to free expression in their pedagogical and educational roles. Freedom of expression in our country is known as one of the most important and basic rights that serves as a widespread blanket for personal expression and autonomy of the individual in society and is part of the characteristics of a democracy. Together with this, it is not an absolute right and, on many occasions, conflict with other rights and obligations of civil servants. In such cases, the right of free expression may take second place to the obligations of civil servants to maintain an objective and neutral position that is not in subservience of a political agenda or position as perceived by the general public or by the specific public with which they come into contact.

It is important to emphasize that in the medical professions (physicians and nurses), the issue of medical courage is discussed as part of the ethical code. Zohar (2000) emphasizes the dilemma that healthcare providers face when asked to testify in court as part of their professional obligation versus what their conscience tells them is right. He underscores the point that, in the medical profession, moral obligation is equal to the obligation required by principles of general morality, but anchoring its principles in professional ethics helps to settle the internal conflict by determining explicitly in advance that medical secrecy will be upheld. In addition, relying on functional morality mobilizes the support of the professional community for the individual facing the judicial system. In an article published on August 2007, Lachman (2007a) discusses several events that demonstrate morally courageous acts of nurses. One of them relates to a dying patient, the second to an intervention of a patient's family, the third to behavior of a colleague, and the fourth regarding management. In each of these case studies, the ethical dilemmas of the nurses are presented and the levels of morality of the alternatives are discussed. The paper was designed to aid nurses in accumulating knowledge about their ethical obligations and, thereby, to foster moral courage among nurses.

Lachman (2007b) defines courage as a virtue and wonders whether it is worthwhile to develop it. She cites an early study that reports feelings of pain and of mental disturbance among nurses who felt obligated to perform certain moral actions, but were prevented from doing so by institutional obstacles (including institutional and ethical limitations). She turns to Aristotle's discussion about courage, but notes that Aristotle refers mainly to physical courage. She then defines moral courage as "a person's ability to overcome fear and stand up for his or her central principles" (p. 131). Morally courageous behavior is demonstrated in deeds and words and can lead to physical injury, although the more common dangers are humiliation, rejection, ridicule, and dismissal from a job.

Moral courage is not only connected to a choice between right and wrong, but also to dilemmas that force us to choose between two right things (between two core values), and even to choose the lesser of two evils. The choice between one right thing and another right one is more difficult than choosing between right and wrong. Lachman discusses the internal conflict between two obligations of nurses, both defined in their ethical code. Morally courageous nurses are willing to perform moral acts even when they know they will have to pay a considerable personal price for it, thereby placing their ethical obligations and core values in the forefront.

Aultman (2008) concludes that discourse with colleagues about experiences relating to ethical dilemmas is an important starting point from which to find solutions to such dilemmas. Discourse among professionals from the 
same field, but from different locations (such as doctors from country areas and urban areas) can promote an understanding of political, emotional, and ethical factors, "and by that intensify moral courage and ethical activity" (p. 67).

\subsubsection{The Price of Moral Courage}

Conformity is when individuals align their behaviors and opinions to existing social norms. Some claims that conformity maintains the social order defines expectations, organizes interactions between individuals, maintains the cohesion of the group and prevents social dissolution (Durkheim, 1983). It also provides a way for individuals to gain perceptions of belonging to a society (Abu-baker, 2002). Through the process of conformity, individuals change their attitudes, opinions or behaviors in order to accommodate to group norms. There is a distinction between conformity that involves attitudinal or cognitive change that characterizes individuals who seek to uphold valid knowledge or to be "right" and conformity that is public or behavioral obedience that characterizes individuals who do not want to be seen as exceptional or deviant and, therefore, do not go against the norms. Furthermore, there is conformity which arises among a member of a group who fears punishment by the group (such as rejection by the group) or conformity that is caused by the desire for reward (such as love or acceptance by the group) (Lehman \& Gonat, 2000). Conformity can be caused by two main reasons: factual influence, when an individual believes that others are right and he is wrong and normative influence, when an individual fears negative consequences for deviating from the norm. In most cases, both influences work simultaneously to cause the individual to conform (Brehm, Kassin \& Steven, 2005). For our purposes, avoidance of moral courage may stem from conformity because, by definition, taking a stand or acting with moral courage is based on the decision to act despite the awareness that society may react with sanctions against the individual who acts with moral courage. Moral courage is not necessarily an act of counter-conformism because the counter-conformist performs an intentional act that is directed against conformity. Moral courage, therefore, is an act of nonconformity. It appears that there are cultural differences in the strength of the appearance of conformity. In societies in which there is high interdependence of members upon one another, there appears to be more pressure for conformity than in societies in which individuals are less dependent upon each other. In societies in which interdependence of members upon one another is high, members perceive themselves as inseparable from the group and conformity is the social "glue" that serves to maintain cohesion among the members (Markus \& Kitayana, 1991).

From this discussion, we can point to different kinds of conformism: conformist compliance that results without an honest belief in the actions, conformist obedience that is an expression of response to a direct command and conformist acceptance that is a result of honest beliefs, thoughts and actions that the group influences us to accept. In some cases, acceptance comes as a result of compliance (Brehm, Kassin \& Steven, 2005). Here is the place to emphasize that morally courageous behavior must be in accordance with moral ethics and that extreme cases of ostracism or racism are not fruits of moral courage.

\section{Methodology}

This paper examines the content fields of the concept of "teachers' moral courage" in order to conceptualize its boundaries. Thus, this paper attempts to identify elements that define behaviors informed by moral courage.

The research question is: what are the elements which define "moral courage" behaviors as it reflected from the teacher's interviews.

The investigation of the subject of this study was carried out through interviews with in-service teachers. Thirty teachers were interviewed for this study, teachers who were considered by the researchers to be able to contribute to the understanding and structure of the concept. The recruitment of the teachers was done by means of personal contact (former collogues as well former students) by the researchers with a request to be interviewed for a study on the subject of moral courage. At this point, it is important to emphasize that we encountered school principals who did not give us permission to interview their teachers. The participant teachers were chosen on the basis of professional acquaintance with them by the researchers or upon recommendations given to the researchers for the reason that these teachers were perceived to have a "say" in the educational field, i.e. each one had left a mark on education. Therefore, the group of teachers is not a representative sample, nor were they chosen randomly. Despite this, the group is comprised of a wide array of representatives: elementary and high school teachers from the secular and religious sectors, as well as novice teachers with less than five years of experience and extremely experienced teachers. The data collected was recorded so that the information would remain verbatim. The interviewees chose the site of the interviews so that a pleasant atmosphere would prevail, one in which distractions could be avoided.

The research adopted a qualitative nature and data analysis was carried out according to interpretive qualitative 
principles as described by Miles and Huberman (1994) in accordance with methods for the building of grounded theory of Strauss and Corbin (1990). For the analysis of the findings, an inductive analysis was performed in relation to the content that emerged from 30 in-service teachers for the purpose of illuminating the meaningful categories that were intrinsic to the verbal content of the interviews. In the final stage, this analysis provided the means by which to describe the reality of the interviewees as perceived and transmitted by them. The study was of a qualitative "defined self-narrative" nature, in which the interviewees related to a defined aspect in their life story (Spektor-Marzel, 2010, p. 67). In the current study, the interviewees were asked to relate to the issue of courage in the teaching process.

The main research tool is the open narrative interview in which the teachers were asked to tell a story or to describe a situation or experience which could shed light, in their opinion, on elements of moral courage that happened to them in the framework of their educational work. The general nature of the question was intended to allow the teachers a nondirective verbal response. This was in accordance with the perspective of Bamberg (2006) that "small stories" that are told in daily interactions form and present the professional image.

The first stage of the inductive analysis included revelatory reading of the content by the researchers that sought to trace the mutual interaction of the terminology that the text sustains with itself and that emerges from it, such as emphasis on concepts and ideas, major motifs and a system of ideational opposites. During this stage, all the data were read in sequence to develop a wide and general orientation that retained the connections between the data (Shkedi, 2010).

The second stage included the division of the content of the interviews in order to identify meaningful units in the text. The verbal content that emerged in the framework of the interviews was divided into sections representative of ideational meanings. Identification of sections with similar meanings throughout the interviews lead to sorting of meaningful units into grounded categories that could be useful for building new meanings among the sections that remained.

In the third stage, the meaning of the content that was created by identifying the connections and the relationships between the categories was restructured and a hierarchical category system was formed with the immersion of similar categories (subcategories) within major categories. Axial coding referring to connections between categories was applied.

Throughout the research, emphasis on the rights of the participants was meticulously observed for the purpose of upholding professional ethical standards and preventing invasion into the privacy of the individuals. As a first step in upholding ethical standards, the purpose of the research and the framework in which it would be carried out was made clear to the participants, as well as the fact that their participation in the research would be dependent upon their agreement. As mentioned, the interviews were recorded and transcribed and the participants were allowed to read the transcripts in order to make sure that what they had said was faithfully.

\section{Findings}

In general, we found the interviewees' answers to express a profound understanding of the concept of moral courage.

The teachers that were interviewed were asked to describe an experience that, in their opinion, involved moral courage in the course of their teaching. Although the teachers' stories were entirely of a personal nature, out of their personal descriptions of their experiences, we identified two phenomena that pointed to common elements.

The first phenomenon exposes levels of action that, according to the teachers, show moral courage in teaching. In the process of building their "morally courageous teaching voice," we found, in the answers of the participants, expressions of withstanding pressure in relation to educational processes connected to the field of ethics and morality. These two fields were defined by us as content domains in which a variety of experiences with common meanings cluster, showing common patterns of action against different factors in the system. In the area of moral ethics, the teachers attempted to describe their ways of functioning in opposition to management, colleagues and didactic materials. In the domain of content of a moral nature, the teachers attempted to engage in discussion related to their inner truth in opposition to parents, management and issues connected to the lives of the pupils. In all cases, the pupil is represented as an image in limbo, whether explicitly or implicitly, in the framework of the total fabric of the content domains. In the two domains of action, professional ethics and morality, the teachers engaged in reflective monologue mirroring their awareness that while their actions were not always in accordance with accepted norms, they, nonetheless, chose to act in such a way.

From the first phenomenon, the second arose repeatedly, pointing to the phenomenon of "the price of action" accompanying morally courageous behavior in teaching. The description of "small stories" led the participants to 
express attitudes in relation to the nature and essence of morally courageous action in light of their experiences with factors in the system that contained a "price" that they would have to pay if they chose to act in ways not in accordance with the system of accepted norms. References to the consequences of their actions were expressed either explicitly or implicitly implied in the examples that they gave.

We shall now present the circles of the teachers attitude towards the subjects of moral courage:

\subsection{Interaction with Students}

The main educational work is done within the framework of the encounter between the teachers and their students. Therefore, it is within this interaction that morally courageous activities are required in a wide range of areas.

\subsubsection{Planning the Lesson and Choosing the Learning Materials}

- $\quad$ "I chose a book in which the Nakba is mentioned. There was much noise in the media about it and pressure was exerted on the school". (9) And another adds "I talk about the Nakba as a historical phenomenon in which people ran away or left, or were expelled, or all of them. I define it, post factum, as the greatest miracle that happened to Israel. We could not have survived here if the Arabs would have stayed. A war would have broken out between the communities". (11)

- I choose to teach content if I feel it is morally right, and if there is a conflict between the content and my personal morals, I do not teach them..." (14) but on the other hand a teacher says: "If there are teaching materials that include principles which I perceive as immoral, I choose not to teach them. And by 'moral,' I mean principles that I deem as accepted by the entire society"...(15)

- I teach what I have to teach. This means that I teach what is determined by the syllabus. So I was never in a situation of conflict referring to teaching content"...(8) or "A teacher should rise up against materials, when these materials are not compatible with the values which he stands for and wants to teach his students according to them. A teacher has a defined role and defined goals. A good teacher, for me, would not agree to teach his students materials that are not compatible with the goals he poses for himself'... (25)

- I do check whether the contents I teach are compatible with the views the school stands for and this is a part of my considerations (28).

\subsubsection{Referring to Political Attitudes}

- "There are many teachers who would choose poems that have no political implication." (6) For example: "I am left-wing and proud of it. Unfortunately, the state exposes hatred, things that upset me; I know I am allowed to express opinions but not to convince. Sometimes I just want to upset a right-wing student and then I say... Therefore, to a certain degree, I do express my opinion”. (8)

- $\quad$ "One can present his own credo and I am not ashamed to present even my political agenda in my lessons." (9)

- $\quad$ "When I have no choice, I express myself loud and clear. Even if I support a certain political stance, I will voice my opinion in a case in which I see that someone is treated with injustice, even if my opinion in this case is not compatible with my general worldview." (13)

- $\quad$ "Even if the contents include an appropriate message that my students should internalize, I will struggle against it if it is contradictory to my political stance. I think I will express my personal political opinion..." "I usually support certain political stances in front of students and teachers, but not with the purpose of instilling in them the same opinions that I maintain. When an ethical issue is discussed that I believe should be dealt with and it requires that I express my political opinion, I will do it without reservation..." (14)

- $\quad$ "I educate for humanistic values. I guide delegations to Poland. There is a lot of criticism about the rightist tendency. There is a lot of nationalism - flags, or sayings such as 'fuck the Arabs'. I try to educate, specifically because of the Holocaust, to be human beings..." (8)

- $\quad$ "I am a socialist at heart. The political issue is very volatile. On the one hand, I have to represent a certain amount of objectivity, but I make sure I show the entire picture. It is important to show that there are also other sides." (12).

- $\quad$ "You may say I quite avoid expressing political attitudes. I also tell my students not to do it, because I know it is forbidden at school"... (26) “" 
- $\quad$ "I, personally, do not express my political views publicly because I know there are students that appreciate me as a teacher, and if I will express views that are not compatible with theirs or their family's worldviews, it will hurt our teacher-pupil relationship"... (27)

\subsubsection{Encouraging Students to Define Their Own Attitudes and Express Them}

- $\quad$ "I allow my students to express their opinions, even political ones, during lessons, but I, as a teacher, do not express political opinions," (15)

- "I teach them to say: "No; I disagree with your opinions". (6)

- $\quad$ "I teach them to present a rationale for disagreements." (8)

- I know that some teachers choose not to present the entire picture, but I believe that students should know the whole picture and express their opinions as they are"... (27)

- $\quad$ "I object to escapism because I believe students should think critically, to confront moral dilemmas by themselves, and if we do not expose them to those dilemmas, they will never be exposed to them on their own"... (1)

- "They should learn and talk about political concepts..." (16)

- $\quad$ "Even if I disagree with a certain content, with what is stands for, I will nevertheless teach it, especially because of the importance of exposing the students to various kinds of content and letting them cope with them"... (21)

- $\quad$ "In highly-charged political periods, we enable the students to talk about politics. For example, a student gave a lecture about the importance of maintaining the Golan Heights, contrary to what I believe in, but she did it so successfully, that I invited her to lecture to all the teachers"...(9)

\subsubsection{Activity among Colleagues}

- $\quad$ "Should one demonstrate responsibility and not just be popular? ... One doesn't have to be such a great anarchist in order to be original". (11)

- $\quad$ "I have to examine it according to several parameters: as a professional teacher, as a homeroom teacher and as a coordinator of the classes belonging to the same grade. As a professional teacher, when I teach history and civics, I have a defined syllabus and an organized curriculum. I can present my credo, and I am not ashamed even to present my political agenda in lessons. We teachers argued among us frequently whether it should be done. [... ]"My presumption is that I educate to be open-minded and to view things critically. If I educate to promote a critical approach, I present my truth."(6)

- I I tell my students everything! Who I voted for in the elections... I tell them what I think, what I feel, what I believe should be done. I believe one can express and share political attitudes. Moral courage means honest behavior. I do not hide behind politically correct statements. I define moral courage as honest behavior in front of the students, even if it is against the expectations of the establishment. A teacher that does not express his opinion is not morally courageous"... (1)

- $\quad$ "I have funny shirts with political statements and they (the students) ask me questions. I give them clues, turning it into a quiz"...(8)

\subsubsection{Behavior in Confrontation with Management}

- $\quad$ "The headmistress did not like the connection and she said no. She was at odds with me and did what she could just in spite. I threatened that if she does not grant him an award, I will not come to the graduation party. She yielded and gave him an award for persistence (but not for distinction)". (1)

- $\quad$ "I face teachers and parents who attempt to meet the students halfway, and I insist upon it - even if the grade is $4^{\text {th }}$ or 5 th, I do not round it off! This is a problem, because there are situations in which we yield, and one should be flexible". (4)

- Activities with Arab schools. I don't know if it takes moral courage to do it. It is not supposed to be morally courageous, but at the level of implementation, it enters into the category of moral courage. In order to travel to an Arab village, we have to convince parents that it will be OK". (11)

- $\quad$ "We invited an Arab lecturer, and people immediately wanted to complain about it. Then they went to the pedagogical coordinator and asked how he could come and how he was invited without permission. In short, we have to confront the system constantly. The teacher is trembling and I have to confront the homeroom class 
teacher." (4). "At the personal level, I saw a student who was abused by her parents and the other teachers buried their head in the sand. I helped her to leave her home." (1)

- $\quad$ "There were also many cases of moral conflicts with the school management, the management had a certain idea, and I had another one. But I did not hesitate to object to the management's decisions"...(14)

- $\quad$ "I pronounce my opinions, my moral principles on every occasion, and I follow them. Especially when facing the management, which does not stand for the same principles that I, as a teacher, stand for"...(28)

\subsection{6 "The Price of Action"}

The interviewees are aware of the fact that a morally courageous behavior might cause a 'price of action' labeled by the school management and other elements, and also mention this as a reason why many of their colleagues avoid morally courageous behavior:

- $\quad$ "Standing up for your truth, for your principles, after clarifying them to the children, after clarifying them to the parents, because headmasters capitulate in a way grown-ups do; It is easier to fire/blame/fault a teacher, in order to please the parents, at the expense of sacrificing the teacher. The desire is not to arouse the Ministry of Education". (2)

- $\quad$ "A morally courageous behavior has its costs; this is how teachers and headmasters feel... My husband tried to shut me up, my friends tried to shut me up, because they knew I would pay a price..." (6)

- "I confronted the headmaster about it and the teachers told me that it was not a wise thing to do". (8)

- $\quad$ "The headmaster called me and I had to explain my consideration for choosing the textbook. The book was excluded from the school curriculum. We do not teach this subject." (9)

- $\quad$ "I think that most teachers are not morally courageous... Here is an example of teachers' failure: teachers who are afraid to raise a controversial issue... for example, the teacher who oversees literature studies and who chooses to teach only subjects within the consensus. There are taboo subjects, such as homosexuality. One can talk but should not preach - this is my belief! ...Even when choosing articles for teaching purposes, teachers choose articles that do not raise confrontation". (1)

- "Other teachers pretend they do not see. They say 'I did not know, I did not hear'.” (11)

- A teacher cannot give an interview - he might pay for it dearly... (5)

- $\quad$ "Personally, I encountered a student whose parents abused her and the other teachers buried their head in the sand. I helped her to get out of her home, took her to a youth promotion office (an agency of the Ministry of Education). Her dad threatened and said: 'You are with me or you are going to heaven,' and I said it's my duty to help her. Friends advised me to leave this issue alone. They said, 'You'll get in trouble' - and I insisted"...(3)

- "As a headmistress, I pay a personally heavy toll for things I believe in"...(7)

- A headmaster did something morally wrong to another teacher. He pushed her to the wall professionally, burdened her with tasks without any reason, and did not explain to her why she should behave the way he wants her to. And being new, this teacher is afraid to respond. I explained to the teacher who suffered from the situation that this is not acceptable behavior and encouraged her not to be afraid. Why should we cower? There are laws; it's not that we did something against the law..."(13)

- $\quad$ The feeling (of a price tag) was there mainly because of cutting corners from my point of view, but also due to the circumstances which existed at the moment of the conflict, like the need for priorities, the dilemma of whether to get involved in a problem that later you would not be able to get out from"... (25)

To sum up, the content fields of moral courage activities in school life refers to:

1) an interaction with students:

a. Planning the lessons and choosing the learning materials

b. Referring to a political attitudes

c. Encouraging students to define their own attitudes.

d. Encouraging students to express ideas

2) Activity among colleagues

3) Behavior in conformation with management

Last but not list, the teachers voices reveal knowledge about the price paid for moral courage behavior. 


\section{Discussion}

"If your standards fit those of your school, then I wouldn't worry." This statement, that reflects a conclusion of one teacher, shows the importance of a basic framework that allows for morally courageous behavior and that prevents ambivalence on the part of teachers concerning the "price" of such action. The support of the school is presented as the reason why the teacher did not give in. The support of the system gives the teacher the confidence to sustain the morally courageous act. Without this support, it is questionable whether the teacher could have act in the same way. Therefore, when the system supports morally courageous behavior in the educational field, teachers are in a position in which they can feel confident in their actions and relate less to the "price" in their discussion of the issue. The "price" becomes a dominant issue in the absence of support by the system.

Our research points to teachers' insights in situations in which they act in accordance with their ethical and moral positions that are in conflict with the spirit of the educational institution in which they teach, with the general spirit of the education system and even with the spirit of Israeli society in general. From the results of the interviews, we found that there is much awareness of the issue of "moral courage" among the teachers of our sample, as well as awareness of the difficulties of implementing it in the field. Our study emphasizes the centrality of the concept of the "price" as it is expressed in the words of the teachers as they perceive the world of the morally courageous teachers who, of necessity, must take into consideration that they may have to pay the consequences for their actions. "I am aware of the price that I may have to pay." At the same time, teachers confessed to being afraid. It may well be that the confession of fear is in itself a morally courageous act. As mentioned, although the "price" is sometimes vague, something that is chosen by the parents, the students or management, there exists in Israel a defined sanction, one that is written in the management circular of the Ministry of Education. From this we deduct that morally courageous behavior cannot exist in Israel as suggested by Klassen, one of the first and foremost spokespersons on the discussion of moral courage in The Netherlands. Klassen (2012) claims that there is a need to lead processes of change in school policy by encouraging staff group work for the promotion of moral behavior. However, in Israel, the organization of the educational system fears dissonance from acts that are not in accordance with the spirit of the institutions. Teachers' discussion of the issue of "price" may be seen as a product of the hidden message transferred by the organizational system that aligns itself with resistance to change in the absence of a widely accepted code of ethics among the teachers of Israel. If there were a code of ethics for teachers, this discussion would not be relevant since any action that deviated from the code would be immediately perceived as a violation. However, in the absence of a professional code of ethics for teaching, the issue of moral courage assumes an important place. Any behavior that violates the spirit of the institution immediately places the teacher in a position of being tested for moral courage. "What are we afraid of?" (Inbar, 2005) According to this question, the author attempts to examine the 'enemies' who threaten the teaching staff as individuals. The importance of the question lies in its emphasis on moral issues: "Ethics in education is not an easy challenge because people must act as individuals according to their ethical commitments, and this may come into conflict with the ethical commitments upon which the educational system is based." The results of our research point to insights that teachers have when they are forced to act in ways that ethically contradict their worldview or that of the institutional climate of the school in which they teach. According to the definition of the concept of "professional ethics" (Kasher, 2003) and its expansion by Schefler (2003), the question is raised regarding how teachers should deal with dilemmas related to courage during the teaching process. Dilemmas are defined as unsolvable problems, having two opposing poles. Each pole has a system of arguments, but against them, there is also a system of counter arguments. Usually, a dilemma hides within it an ethical-moral conflict that does not allow for a clear and unambiguous solution, even when the dilemma relates only to immediate time and local circumstances. A problem, on the other hand, according to their view, is a conflict that is created due to obstacles lying on the path that leads to a certain solution. They found dilemmas of teachers related to issues such as decency and concern, privacy, dignity, freedom and coercion. Since society is not represented as a client or as a source of authority, the moral basis of teachers' work is left to individuals. When individuals are required to choose moral behavior, they must examine their priorities against all the behavioral dictates that have been established and integrated into society through socio-historical processes versus their own personal and group interests. The problem is that in teaching, there are no ethical behavioral dictates (in the absence of an ethical code), but rather disciplinary rules and management regulations. What are the group's interests? Who is the group? What are the personal interests? The interest may be not to be courageous and not to pay the price.

The process of consciousness plays a meaningful part in individual moral conceptions. Sometimes a personal truth might seem unreasonable and invalid to the individual who voices it because our instincts revolt against an 
awareness of the truth expressed in a saying in the presence of an inability to fulfill the action behind the saying due to the fact that a large part of our "logic" is comprised of group logic.

\section{Recommendation}

In the absence of a professional ethical code for the teaching profession, the issue of moral courage assumes greater importance. In the present situation, the point of confrontation of a behavior that violates the institutional climate puts teachers immediately to the test that determines their amount of moral courage.

In addition to our call to the teachers' unions and the Ministry of Education to complete the work on an ethical code for teachers in Israel, we believe that there is no point in standing on the sidelines and waiting for this to happen. In the absence of an ethical code, the decision of whether to engage in moral behavior is relegated to the realm of personal decision-making that may contradict management regulations or the institutional climate, thereby turning the moral act into courageous moral behavior. But since we maintain that only a minority of teachers would rather risk endangering themselves to act in morally courageous ways, the training institutions that educate teachers should pick up the gauntlet and undertake the work to nurture as many morally courageous teachers as possible. In other words, because we are not sure that the teachers' unions and the Ministry of Education, which are in charge of the educational system in Israel, will indeed work toward the establishment of an ethical code for the teachers in Israel, we maintain that teacher education institutions should integrate the development of moral courage as one of their objectives.

Initial teacher education institutions should dedicate an entire course, or several segments of courses such as philosophy of education or ethical education, to this subject. Additionally, the fostering of moral courage should be defined as a central axis in many other courses (pedagogy and didactics, for example). The teaching of this subject should include theoretical discussions about main concepts that promote attitudes of ethical and moral conceptions, as well as include a central segment of practical simulations, test cases, and role playing.

We perceive the education of morally courageous teachers as an essential and preliminary condition for the possibility of introducing humanistic ethics and democratic civics into the schools. In the meantime, the five elements mentioned above can be used by teachers training institutions for fostering morally courageous teachers. For some teachers, this activity in their initial teacher education will provide an adequate basis for transforming them into morally courageous teachers. Other teachers will gradually adopt moral courage in the course of their actual teaching careers as they build upon their experience in the field. Thus, the fostering of moral courage in teachers should also constitute a requirement in continuing professional development courses. Although it is not too late, we believe that the time has come and the sooner, the better.

\section{References}

Abu-Baker, H. (2002). Eleven comments about otherness, equality and multiculturalism. Panim, 22, 32-38.

Aloni, N. (2006). Education and humanism. Panim, 36, 5-9.

Aultman, J. (2008). Moral courage through a collective voice. The American Journal of Bioethics, 8(4), 67-69. http://dx.doi.org/10.1080/15265160802147140

Ayalon, I., \& Sabar, N. (2010). Analysis content according to grounded theory. In L. Kasan \& M. Krumer-Nevo (Eds.), Qualitative investigation data analysis (pp. 359-382). Ben-Gurion University Publishers.

Bamberg, M. (2006). Biographic-narrative research, quo vadis? A critical review of "big stories" from the perspective of "small stories." In K. Milnes, C. Horrocks, B. Roberts, \& D. Robinson (Eds.), Narrative, memory and knowledge: Representations, aesthetics and contexts (pp. 63-79). Huddersfield, UK: University of Huddersfield Press.

Baratz, L., \& Reingold, R. (2010). The ideological dilemma in teaching literature process-moral conflicts in a democratic and nationally diverse society: An Israeli teacher case study. Current Issues in Education, 13(3), 79-93.

Brehm, S. S., Kassin, S., \& Steven, F. (2005). Social psychology (6th ed.). New York, NY: Houghton Mifflin Company.

Durkheim, E. (1983). Suicide: A study in sociology. London: Routledge (first published in 1897).

Graff, G. (1992). Beyond the culture wars: How teaching the conflicts can revitalize American education. New York: W. W. Norton \& Co.

Graff, G. (1994). Teaching the conflict: Gerald Graff curricular reform and the culture war. N.Y. \& London: Garland Publication. 
Inbar, D. (2005). Ethics and education: What are we afraid of? In E. Paldi (Ed.), Education and challenge of time 2 (pp. 560-573). Even Yehuda: Reches Educational Projects Ltd.

Kasher, A. (2003). Professional ethics. In G. Schafler, Y. Achmon \& G. Weil (Eds.), Ethical issues in counseling and psychological treatment (pp. 15-29). Jerusalem: Magnes Publishers.

Kidder, R. M. (2005). Moral courage: Ethics in action. New York: Harper Paperbacks.

Klaassen, C. (2012). Just a teacher or also a moral example? In D. Alt., \& R. Reingold (Eds.), Changes in teachers' moral role: From passive observers to moral and democratic leaders (pp. 13-30). Rotterdam, the Netherlands: Sense Publishers.

Klaassen, C., \& Maslovaty, N. (2010). Teachers and normative perspectives in education: An introduction. In C. Klaassen \& N. Maslovaty (Eds.), Moral courage and the normative professionalism of teachers (pp. 1-12). Sense Publishers: Rotterdam.

Klaassen, C. (2007). The moral role of teachers investigated. What did we learn? Paper presented at the 2007 annual convention of the American Educational Research Association, Chicago.

Lachman, V. D. (2007a). Moral courage in action: Case studies. Nursing, 16, 275-277.

Lachman, V. D. (2007b). Moral courage: A virtue in need of development? MEDSURG Nursing, 16, 131-133.

Markus, H., \& Kitayana, S. (1991). Culture and the self: Implications for cognitions, emotion, and motivation. Psychological Review, 98, 224-253. http://dx.doi.org/10.1037/0033-295X.98.2.224

McCain, J., \& Salter. M. (2004). Why courage matters. New York: Random House.

Miles, M. B., \& Huberman, A. M. (1994). Qualitative data analysis (2nd ed.). Thousand Oaks, CA: Sage.

Miller, I. (2000). The mystery of courage. Cambridge, MA: Harvard University Press .

Oplatka, I. (2007). Organizational citizenship behavior in school: The concept, its determinants and elements among primary and secondary school teachers. Dapim, 44, 33-64.

Reshef, A. (2002). Organizational ethical culture and moral principles: Basic demands for promotion of organizational learning processes. Mashabi Enush, 173, 16-20.

Rorty, A. (1988). Mind in action: Essay on the philosophy of mind. Boston, MA: Beacon Press.

Sabar, N., Dushnik, L., \& Bialik. G. (2007). Who am I to decide their fate? Teachers' ethical dilemmas. Jerusalem: Magnes Publishers.

Schefler, G. (2003). Professionalism. In G. Schefler, Y. Achmon \& G. Weil (Eds.), Ethical issues in counseling and psychological treatment (pp. 75-87). Jerusalem: Magnes Publishers.

Shermer, O. D. (1999). Education in Israel between radicalism and tolerance. Jerusalem: The Magnes Publishers.

Shkedi A. (2010). Multiple Case Narratives: A Qualitative Approach to Studying Multiple Populations. John Benjamins Publishing Co.

Spektor-Marsel, G. (2010). The story is not the whole story: The narrative identity card. In L. Kasan \& M. Krumer-Nevo (Eds.). Qualitative investigation data analysis (pp. 63-96). Ben-Gurion University Publishers.

Strauss, A., \& Corbin, J. (1990). Basics of qualitative research: Grounded theory procedures and techniques. Newbury Park, CA: Sage Publications, Inc.

Tillich, P. (1952). The courage to be. New Haven, CT: Yale University.

Zohar, N. (2000). Ethics and professional emancipation. In D. Izraeli \& N. Zohar (Eds.), Ethics and social responsibility, Israeli studies (pp. 74-82). Tel Aviv: Chericover Publication. 